\title{
BIOLOGY OF THE SLATECOLOURED BOUBOU AND OTHER BUSH SHRIKES
}

\author{
EdITH SONNENSChein \& Heinz-UlRich ReYer \\ Max-Planck-Institut für Verhaltensphysiologie, D-8131 Seewiesen, West Germany \\ Received February 1984
}

\begin{abstract}
SUMMARY
Sonnenschein, E. \& Reyer, H.-U. 1984. Biology of the Slatecoloured Boubou and other bush shrikes. Ostrich 55:86-96.

Breeding biology of Laniarius funebris at Baringo (Kenya) was studied in three consecutive seasons from 1980-82. Details are given of the habitat of the observed population, its territories and aggressive behaviour. Nests were built at an average height of 1,5 $\mathrm{m}$ and 2-3 eggs were laid. Incubation lasted 17 days and was usually shared by both parents. Development of one nestling was recorded in detail. Predation on eggs and young was very high; the behaviour of only one juvenile could be observed after leaving the nest. The second part of the paper reviews what is known of the other bush shrikes in the genera Laniarius, Malaconotus (including Telophorus) and Tchagra. It is concluded that available information on plumage, distribution and habitat, nesting and feeding habits and vocalization is not sufficient to allow any general statements about relationships between ecological conditions and behaviour, duetting in particular.
\end{abstract}

\section{INTRODUCTION}

The duetting song of the Slatecoloured Boubou Laniarius funebris has been intensively studied in East Africa and various interpretations have been made as to the function of this behaviour (Hooker \& Hooker 1969; Thorpe 1972; Wickler 1972; Wickler \& Seibt 1979; Sonnenschein \& Reyer 1983). Several of these studies have arrived at very different results, especially as far as the functions of duets are concerned. This may partly reflect real differences between study populations, but discrepancies may also result from the fact that most authors confined their studies to different times of the year, to selected aspects of the birds' biology and/or were not able to correlate vocalizations with detailed behavioural observations which are difficult to obtain in the birds' dense tropical habitat.

As we have shown recently (Sonnenschein \& Reyer 1983), such complementary behavioural observations are extremely helpful for analyzing the structure, function and amount of duetting, particularly in species having different duet types. In that study we confined behavioural descriptions to the minimum necessary for understanding the vocalizations of $L$. funebris. In this paper we present more details, especially on the breeding biology of the species, and give a brief comparative review of the other bush shrikes, with special emphasis on duetting. The aim of this paper is to compile as

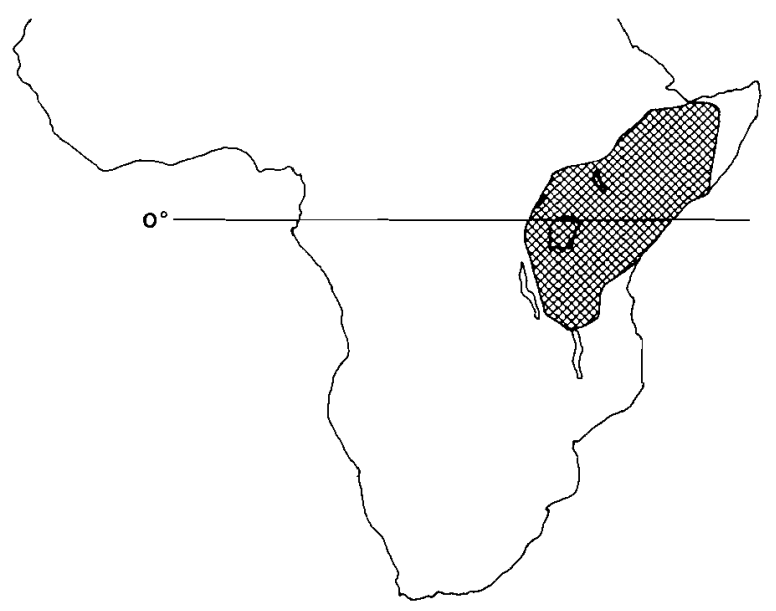

FIGURE 1

Distribution of Laniarius funebris in East Africa (after Hall \& Moreau 1970).

much information as possible and, by drawing attention to lacking data, to stimulate further investigations into relationships between ecology and the behaviour of closely related species.

\section{THE BIRD}

L. funebris belongs to the bush shrikes (Malaconotidae) and is a widespread resident in East 
Africa ranging from southern Sudan to southern Tanzania (Fig. 1). It is one of four entirely dark unpatterned boubou species, the others being $L$. leucorhynchus, L. poensis and L. fuelleborni. They are mostly sympatric but are found in different habitats. $L$. funebris inhabits the lower dry bush country below $1500 \mathrm{~m}$, where it keeps to thickets and fringes of forest.

Seen in good light, L. funebris is a deep slateblue colour, but usually the bird gives the impression of being wholly black. Only the rump feathers have some white spots which are normally concealed by the wings. Bill, eyes and legs are also black. The sexes look similar, both in colour and size. From museum specimens and live birds we found that males have a slightly longer bill than females $(220 \mathrm{~mm} v s .210 \mathrm{~mm} ; \mathrm{n}=47, \mathrm{p}<0,01$; t-test $)$ and may be a bit heavier $(40,8 \mathrm{~g} v s .38,8 \mathrm{~g} ; \mathrm{n}=10$, n.s.). Discrimination of sex in the field was based entirely on the calls which are sex-specific. Neither in the field nor in captivity did we find evidence of males mimicking females or vice versa. The young bird is dull black with breast and belly more or less barred tawny; there is the merest indication of a hook at the tip of the upper jaw.

The birds live in pairs defending territories. Their presence is generally revealed by frequent duetting between male and female. Although shy and retiring like most bush shrikes, L. funebris is inquisitive and can be attracted by strange noises. The birds may then leave the dense cover and mount higher trees, from where they often start long duet series. Reluctant fliers, they avoid crossing open country.

\section{MeTHODS}

Breeding habits of five pairs in their territories were studied at Lake Baringo (Kenya) in the months April, May and June of 1980, 1981 and 1982. (Observation periods in September 1980 and March 1982 were in the dry season without reproductive activity.)

Trapping of the birds for colour-ringing proved extremely difficult. Use of mist nets was prevented by the dense vegetation of the habitat. Though playback generally attracted the birds, response and approach were made in the higher strata of trees. Some success was achieved with a spring trap placed on the ground. This was tried before the 1982 breeding season, when the ground was still devoid of grass. Traps were baited with a mealworm and had to be concealed with dead leaves as the birds were very suspicious. Two birds were captured thus, first a young male which kept a small territory, but without a mate in the following breeding season. This bird was also acoustically recognizable by his still half-developed voice. The second bird captured was a mated adult female. All other individuals in the observed population remained unidentifiable, except one male with a bill deformity. For this reason, one cannot say confidently that any two birds occupied their territory for longer periods. However, considering the different behaviour and habits of closely observed pairs, this was assumed to be the normal case; for example most of the data were obtained from a pair whose activities at the nest could be observed easily by sitting only a few metres away; observations in other territories had to be made from a hide.

\section{Study Area}

Lake Baringo lies some $65 \mathrm{~km}$ north of the equator at an altitude of $900 \mathrm{~m}$. The climate in this area is generally hot and dry. The Baringo district was once covered by a wooded savanna. Increasing erosion in recent years due to overgrazing has made most of the area semi-arid, with thornbushes predominating. Some places have resisted this development, and there $L$. funebris is still frequent. The observed population lived near a high lava cliff stretching parallel to the west side of the lake, about $2 \mathrm{~km}$ from the shore. Because of the rocky ground, the vegetation in some of the birds' territories was less dense, allowing us to walk between or creep under the bushes and thus giving us a chance to find nests. The bush vegetation included Salvadora persica, Commiphora africana, Acalypha fruticosa, interspersed with high trees (Acacia). In the dry season bushes stay leafless and the ground remains bare. They become lush only during and shortly after the rains.

\section{DIET}

L. funebris is mainly insectivorous; birds in captivity take fruits occasionally. In the wet season caterpillars formed an important part of the diet of 
adults and nestlings respectively. The birds search for their prey on the ground only in the dry season when there is no grass, or gather insects from leaves while hopping through the bushes. Big items are handled by "wiping" them to and fro against a branch before swallowing. Impaling of food, a typical behaviour of the Lanius shrikes, was never observed, and Thorpe (1972) assumes that it is absent in all Laniarius species. However, it was performed by a captive Tropical Boubou $L$. aethiopicus, which stuck pieces of ox heart onto branches in its aviary (pers. obs.). Langley (1983) reports that a pair of Southern Boubous $L$. ferrugineus ate snails by lodging them into crevices in order to pull out the fleshy part. Kaumanns (1975) observed regular impaling by a captive $L$. ferrugineus.

\section{Territoriality AND Aggression}

The sizes and shapes of territories varied with natural boundaries such as cliffs, or open areas which the birds avoid, and/or as a result of population density and further unknown factors. One territory we mapped was 3,5 ha in size, but others were only about half as large. Usually the territories were contiguous, but isolated patches of bush were also populated if they were large enough (minimum about $1,5 \mathrm{ha}$ ).

Another population of $L$. funebris existed close to the lake shore in a woodland area with impenetrable undergrowth. Here, observation of the birds was extremely difficult and searching for nests impossible. Playback experiments gave the impression that territories were smaller than in the more open habitat near the cliff. The two populations were separated by Acacia savanna.

Sometimes a third bird was present in a territory. At least in cases of females, this extra bird might sing with the resident male in a duet, just as the resident female did. Before the 1982 breeding season, a fight between two females was observed, in the course of which one attacked and chased the other. The male did not take part but continued singing in a tree. The significance of such same-sex aggression was discussed in Sonnenschein \& Reyer (1983). It is assumed that these additional birds were offspring of the previous year. They left the territory before the next breeding season commenced; there are no reports about helpers at the nest in any Laniarius species (Grimes 1976).

Territories were defended throughout the year but reaction to intruders (real or playback) varied greatly, depending on the stage of the breeding cycle. In the dry season and also during incubation, the birds' readiness to defend was very low, judging from playback experiments and the rare occasions when conspecifics could be observed entering an occupied territory. In three cases of boundary transgressions, the intruders were neighbouring pairs which had recently lost their clutches to predators. In the pre-breeding season and during nest building, defence might not only be acoustic but physical attacks were also probable.

When attracted by conspecific song played from a tape recorder, birds behaved in different ways. One territory owner followed the "intruder" well beyond his boundary into open savanna. In another incident a strange bird, probably from a neighbouring territory, appeared flying over the sound source, while the resident pair duetted nearby. Most of the these observations concerning territorial defence could not be followed satisfactorily, owing to the poor visibility in dense vegetation and unmarked birds.

\section{BREEDING SEASON}

Breeding of $L$. funebris coincided with the rainy season when protection for nests and supply of insects usually was highest ( $c f$. Folse 1975; Brown \& Balda 1977). The rains normally began in March/ April and extended to August, but some rain might occur in every month of the year. Fig. 2 shows the variation in rainfall pattern of the years $1980-82$, measured within $2 \mathrm{~km}$ of the study area (J. H. E. Leakey, pers. comm.). First nests were found one to three weeks after the initial rainfall. No precise comments can be made on the termination of breeding. It continued as long as conditions seemed favourable, though we did not measure insect abundance or foliage density. An observation period in September 1980 revealed no reproductive activity, although there had been some rain before (Fig. 2).

\section{Nest AND EgGS}

Of the 24 nests found, 17 were an average height of $1,5 \mathrm{~m}$ above ground, three were at $2 \mathrm{~m}$ or higher, 


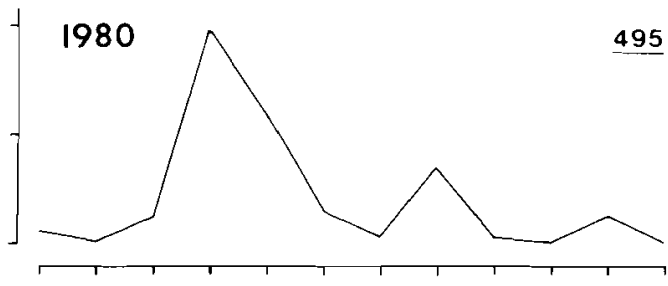

1981 675
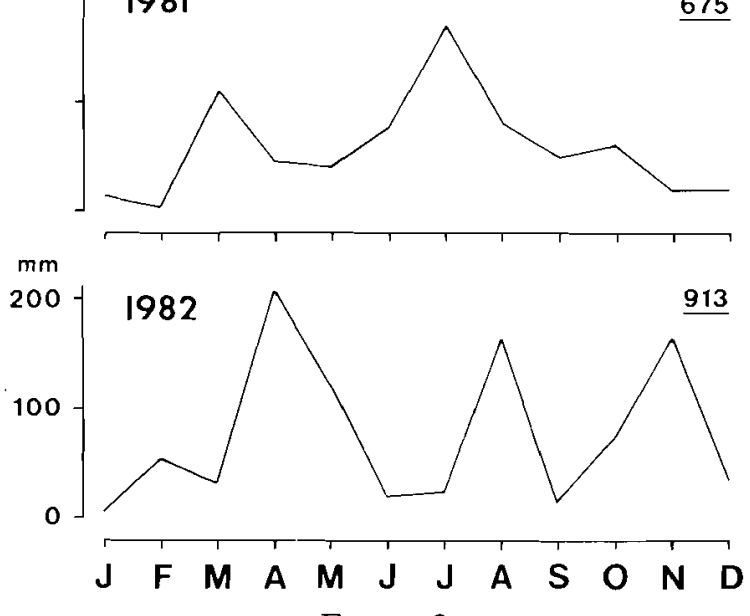

Figure 2

Rainfall pattern at Lake Baringo in the three years of study. Underlined figures (right) represent the total amount of rain in $\mathrm{mm}$ for each year.

and four were below $1 \mathrm{~m}$. Nests were cup-shaped, usually well hidden and (especially in dense bush) difficult to find. However, half of them had been placed in the forks of small trees, where the nest was in fact more conspicuous but had better support. Material for construction consisted mainly of shreds of bark fibre which the birds stripped from dead branches. More delicate material such as blades of grass and rootlets were used for lining the cup. The outer wall was sometimes covered with spider web. The inside diameter of the nest measured about $7 \mathrm{~cm}$. Some nests were rather poorly bound; in one case the weight of growing nestlings caused the nest to collapse, spilling its contents to the ground. Time for nest construction varied between 1 day and 1 week $(\mathbf{n}=9)$, depending on the stage of the breeding season (first nests usually took longer than later ones), the number of nests under construction (see below), and the relative contribution of the sexes. Though usually both sexes participated in nest building, males often contributed less and in some cases might not take any share at all.

Four observed copulations all occurred in the nesting tree shortly after completion of the nest. The female was seen crouching with quivering wings before her mate mounted. Copulation lasted a few seconds after which the male might utter $k c h$ calls. There was no evidence for courtship feeding.

The 2-3 eggs were laid on consecutive days (18 clutches with 2 eggs, three with 3 eggs). They were pale blue with reddish-brown spots becoming more concentrated at the blunt pole. One female was actually observed laying the second egg. During the process, she half lifted herself out of the nest and showed signs of effort. Shortly afterwards, the male flew to the nest, probably in order to relieve his mate. The female refused to leave, opening her bill towards the male which tried in vain to coax her with quiet contact calls. Changeover then took place several minutes later.

If a clutch was lost the birds usually built a new nest. Some unsuccessful pairs produced at least three clutches in one season. Occasionally a nest under construction was abandoned and another was started in a different place, often using the material from the first for the new one. One pair which had lost its single nestling the previous day was observed building three nests simultaneously, but soon concentrated on one which was completed and furnished with a replacement clutch.

\section{INCUBATION}

Incubation started with the first egg laid. Usually both sexes took regular turns incubating and later brooding the young. Nest relief was coordinated by the mates acoustically. This was described in detail by Sonnenschein \& Reyer (1983). Average incubation bouts were for females 40,6 $\min (\mathrm{SD}=17,9 ; \mathrm{n}=66)$ and for males $48,3 \mathrm{~min}$ $(\mathrm{SD}=23,1 ; \mathrm{n}=68)$. In one pair the male sat on the nest for short periods only, while the female did the major share. In another pair the male did not participate at all, he was even driven away by the female when he once appeared near the nest. Average incubation bouts of this particular female lasted $37,2 \min (\mathrm{SD}=25,4 ; \mathrm{n}=10)$ interrupted by 
average pauses of $16,5 \min (\mathrm{SD}=7,8 ; \mathrm{n}=11)$, during which the female foraged.

Neighbouring birds of other species which chanced to come near the nest were chased away. The reaction of an incubating bird when approached by humans varied individually. Some would slip off the nest when the observer was still a distance away, others were more tolerant and left only reluctantly. When we inspected a nest, the bird which had been incubating or brooding would generally stay close by, hopping around and uttering alarm calls. All $L$. funebris were sensitive to human voices, which would invariably cause an incubating bird to leave the nest.

\section{The Nestling}

In four observed cases, eggs hatched after 17 days of incubation. Egg shells were carried away by the parents, just as were eggs which failed to develop. The nestling was blind and completely naked with a black skin and conspicuous yellow gape. Duration of brooding was different in pairs, but generally lasted from a few days up to about a week. At one nest containing three nestlings aged 1-3 days, the female protected the young by spreading her wings over them during a shower of rain. Besides keeping nestlings warm, brooding also served as protection from the sun. Once when a shaft of sunlight reached into the nest, the unprotected nestling tried to move away from it. Food was brought by both parents, in the first days green caterpillars exclusively, thereafter other insects as well. Begging by the young was very quiet. Immediately after feeding, a faecal sac was produced, which in the first days was swallowed by the parent but later on usually carried away.

Growth and plumage development were recorded daily for one juvenile. Starting with $3 \mathrm{~g}$ at hatching, the nestling's weight increased almost linearly from $6 \mathrm{~g}$ at day 3 to $33 \mathrm{~g}$ at day 15 . Feather tracts became apparent at the age of 5 days; eyes opened on the 8 th day. First feathers to emerge were on the rump at 9 days. At 12 days of age the nestling was fully feathered but with wings and tail still short. It was now beginning to do some exercise: preening, stretching legs and wings, standing up, and thereby often losing balance. Begging calls became louder and can be described as a plaintive seee. The plumage of the nestling just before leav- ing the nest was black, each feather tipped with buff. On the 16th day the nestling had disappeared, obviously fallen victim to a predator as its parents were already building a new nest.

Unfortunately, a successful rearing could never be observed. Sooner or later, all eggs or nestlings were robbed (eggs disappeared in 12 cases, nestlings were robbed in five cases). The actual nest remained untouched in most cases of robbery, and was only occasionally destroyed. The cause for this high predation pressure seems to be the Nile Monitor Varanus niloticus, although other animals might also be responsible. The presence of an observer might also have been a limiting factor in breeding success, since mammals are known to follow human tracks.

\section{Post-Nestling Period}

In a territory outside our study population a young bird was found which had probably left the nest a few days before, though the nest could not be found. This juvenile was fully capable of flight; its tail was at first very short but grew rapidly. It also managed to feed itself although begging calls and quivering of wings were performed every time a parent came near. The bird was kept under observation for the following two weeks and its vocalizations were recorded. They consisted of a mixed babble of high and low sounds and bore no resemblance to the adult song. Once the vocalizations were answered by the female with her duet part. The buff-spotted plumage of the juvenile changed gradually into the uniform slate colour of the adults. From hand-reared birds we learned that the complete change takes about $6-7$ weeks. (One of our captive female $L$. funebris from a population in Tanzania, still bears its juvenile plumage at the age of 4-6 months.)

\section{Review of THe Bush Shrikes}

In Table 1 we have assembled the available information on plumage, vocalization, feeding, nesting and other habits as well as on distribution and habitat for 36 species of bush shrikes. This information was derived mainly from standard reference works (Bannerman 1953; Chapin 1954; Mackworth-Praed \& Grant 1955, 1973; Archer \& Godman 1961; Hall \& Moreau 1970; Benson et al. 
1973; McLachlan \& Liversidge 1980; Serle \& Morel 1980; Williams \& Arlott 1980; Louette 1981; Irwin 1981; Wolters 1982). Except for distribution and plumage, all information is scanty. Moreover, descriptions of breeding biology and behaviour may be based on single observations only, or different references may even contradict each other. Therefore the following review and deductions drawn therefrom must be considered tentative.

\section{Taxonomy}

The term "bush shrike" is generally applied to four genera of the family Malaconotidae: Laniarius, Malaconotus (including Telophorus) and Tchagra, comprising 36 species altogether. Originally they were placed within the Laniidae on account of similarily hooked bills. However, field observations have revealed a completely different behaviour from that of Lanius, the true shrikes. In our definition of typical bush shrikes we follow the suggestion of Hall \& Moreau (1970). The taxonomic status of species and races is still subject to discussion in various reference works, $e . g$. Wolters (1982) considers Nicator a bush shrike, whereas most authors now place it in the family Pycnonotidae (bulbuls).

The separation of the genera Chlorophoneus and Telophorus has been abandoned in recent works in favour of Malaconotus. The old classifications, based on museum specimens, are constantly being modified in the light of behavioural observations. A good example here is the Laniarius ferrugineus group. The former races aethiopicus, bicolor and turatii have now species rank according to vocal variation, distribution and different habitats (North \& Haagner 1964; Hall \& Moreau $1970)$.

\section{Plumage}

Plumage of the birds has been adequately described in handbooks and field guides; we consider here only whether a species is sexually monomorphic or dimorphic. Monomorphic means the sexes are alike to very similar. The female may be duller in plumage or may show minor differences in colour pattern, hardly noticeable in the field. $L$. ferrugineus and L. ruficeps are (rather reluctantly) noted as sexually dimorphic. Their females have differently coloured backs, although this may not always be very distinct within certain races.

The genus Malaconotus is renowned for its bright colours. This is particularly true for $\mathrm{M}$. $\mathrm{mul}$ ticolor, nigrifrons and olivaceus, which are not only dimorphic, but the males may show up to five different colour forms. This polymorphism, its evolution and relationship within the genus Malaconotus, has been fully discussed by Hall et al. (1966). In the genus Tchagra, only minuta is dimorphic. The female has a narrower white line above the black lores.

\section{Distribution and habitat}

The bush shrikes are confined to the Afrotropical Region; only $T$. senegala reaches the Palaearctic Maghreb. Bush shrikes inhabit all kinds of wooded country where they keep to dense vegetation. According to Table 1 they seem to occur more frequently in densely wooded habitats of considerable area (e.g. montane and lowland forests) than in open woodlands (e.g. dry thornbush, open savanna, gardens and cultivations). Some species are present in more than one of the listed habitats, and differences in habitat use between races or even populations also occur.

\section{Habits}

Most bush shrikes are cryptic skulkers. Only four species (Laniarius bicolor, Malaconotus zey. lonus, Tchagra minuta and T. senegala) perch frequently in the open as Lanius species do. The number of species obtaining their food on the ground or among the foliage of low bushes is greater than the number of tree-top feeders. All bush shrikes are largely insectivorous.

\section{Vocalizations}

Loud distinctive calls compensate for the low visibility of bush shrikes and are a useful means of identification. Calls have been described onomatopoeically for almost all species, but only few sonagrams are available. In Figs 3-7 we present some additional sonagrams produced from our own recordings and from those available on commercial records and cassettes. Most bush shrikes have a wide repertoire of vocalizations. Furthermore, dialects seem to be widespread, often resulting in completely different song patterns of conspecifics living in different localities. Contrasting with this variety is the uniformity in some alarm calls. The 


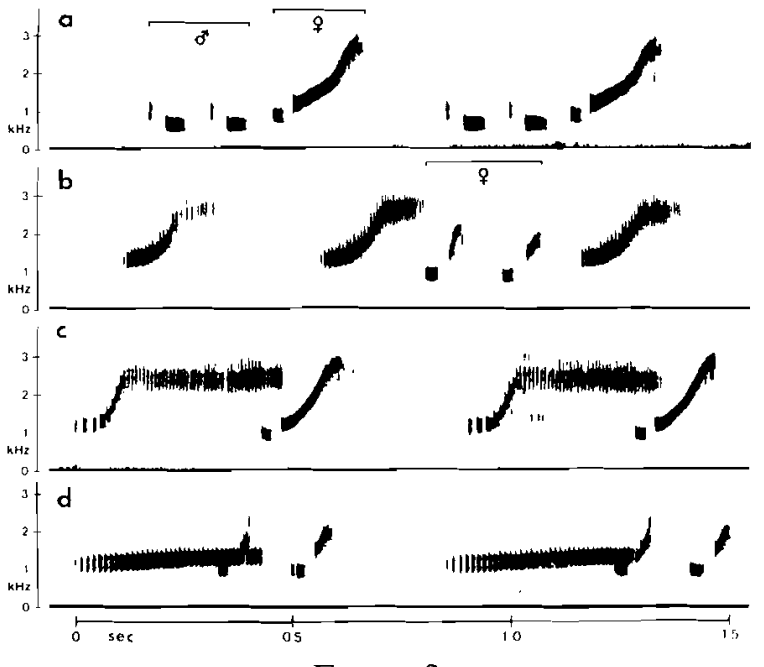

FIGURE 3

a-d: Four duet types of Laniarius funebris from Lake Baringo.

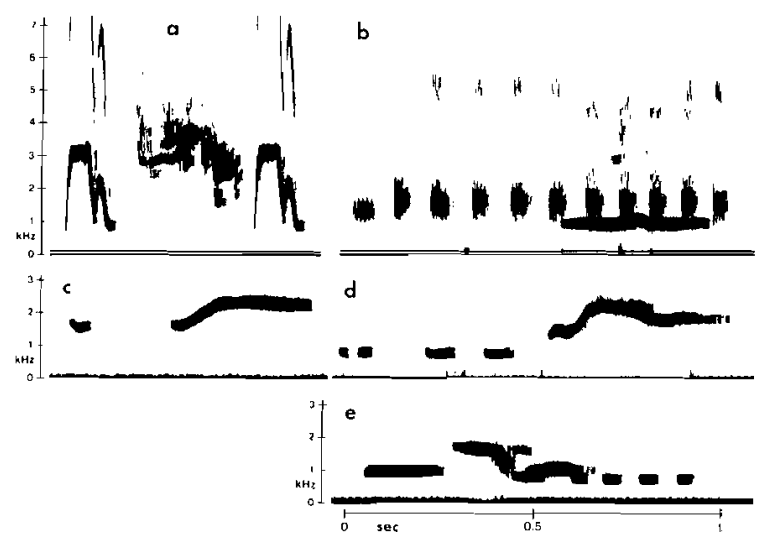

FIGURE 4

a: Laniarius atrococcineus (I), b: Laniarius bicolor (I), c: Laniarius ferrugineus (IV), d: Laniarius ferrugineus (V), e: Laniarius aethiopicus (II). I = by courtesy of Transvaal Museum; II = "Birds of Kenya" (record); III = "Birds of Amanzi, Eastern Province" (record); IV = "Bird songs of the forest. Eastern Cape Province and Zululand" (record); V = Natal Bird Club; VI = "Birds of the African rain forest" (record).

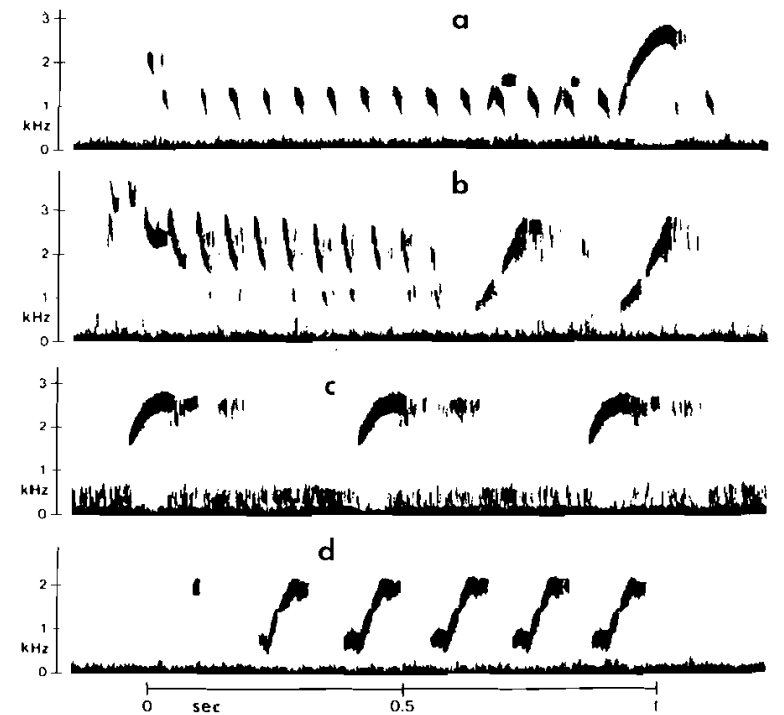

Figure 5

$\mathrm{a}, \mathrm{b}$ : Laniarius fuelleborni (VI), c, d: Malaconotus dohertyi (VI). I = by courtesy of Transvaal Museum; II = "Birds of Kenya" (record); III = "Birds of Amanzi, Eastern Province" (record); IV $=$ "Bird songs of the forest. Eastern Cape Province and Zululand" (record); V = Natal Bird Club; VI = "Birds of the African rain forest" (record).

$k c h$ and teck described by Sonnenschein \& Reyer (1983) for L. funebris occur almost identically in L. ferrugineus, L. aethiopicus and L. erythrogaster. Another widespread note is the female song type in duets of $L$. funebris from Lake Baringo (Sonnenschein \& Reyer 1983). This particular type appears, with some variation, in several songs of bush shrikes, probably regardless of sex.

The high number of duetting bush shrikes is remarkable. However, while all Laniarius species seem to be duet singers (Thorpe 1972), only four Malaconotus species are known to duet. Whether this is a real difference between the two genera or whether it reflects less direct observation in Malaconotus remains to be seen. Merely hearing a song alone does not usually permit differentiation between duetting and solo singing. $M$. blanchoti, for example, has never been reported to duet, but the overlap of different notes in our sonagram suggests 

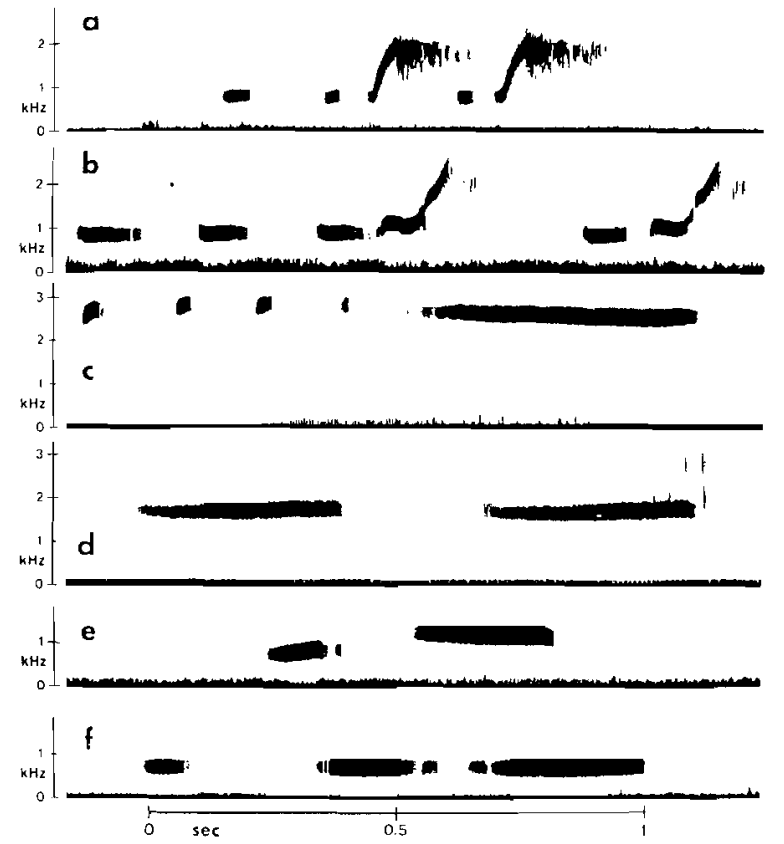

Figure 6

a: Malaconotus quadricolor (Natal), b: Malaconotus viridis (VI), c: Malaconotus sulfureopectus (Baringo), d: Malaconotus blanchoti (II), e: Malaconotus nigrifrons (VI), f: Laniarius leucorhynchus (VI). I = by courtesy of Transvaal Museum; $\mathrm{II}=$ "Birds of Kenya" (record); III = "Birds of Amanzi, Eastern Province" (record); IV = "Bird songs of the forest. Eastern Cape Province and Zululand" (record); V = Natal Bird Club; VI =

"Birds of the African rain forest" (record).

that it is a duetting species. On the other hand the songs of $M$. quadricolor and $M$. viridis resemble the duet of $L$. funebris, but are given by the males alone (Wickler \& Seibt 1982).

\section{Breeding biology}

Probably all bush shrikes live in monogamous pairs and are highly territorial. A special behaviour in the genus Tchagra is the courtship flight: the male rises steeply into the air with rattling wings, then floats down again while uttering the song. Bush shrikes usually construct their open cup-shaped nests in a tree or bush at variable

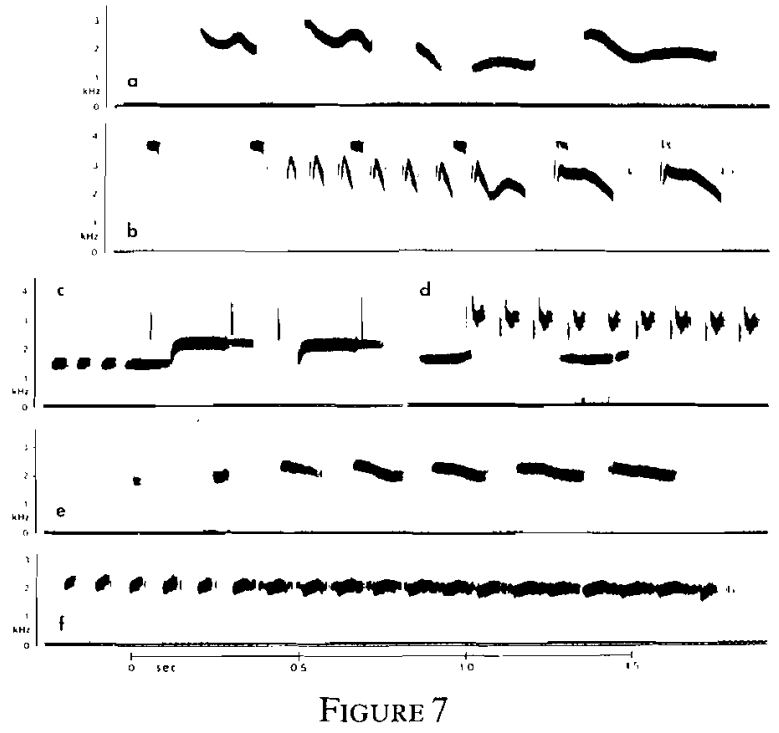

a: Tchagra senegala (II), b: Tchagra tchagra (III), $\mathrm{c}, \mathrm{d}$ : Malaconotus zeylonus (I), e: Malaconotus olivaceus (III), f: Malaconotus olivaceus (V). I = by courtesy of Transvaal Museum; II = "Birds of Kenya" (record); III = "Birds of Amanzi, Eastern Province" (record); IV = "Bird songs of the forest. Eastern Cape Province and Zululand" (record); V = Natal Bird Club; VI = "Birds of the African rain forest" (record).

heights. The eggs are speckled and number two or three in most species; only $M$. blanchoti and $M$. zeylonus have been reported to lay four eggs occasionally. Incubation and nestling periods are known for a few species only ( $L$. atrococcineus, $L$. ferrugineus, $L$. funebris, $M$. zeylonus), being 16-17 days for incubation and 16-20 days for nestling period. In L. atrococcineus (Tarboton 1971), L. aethiopicus (Thorpe 1972) and L. funebris (Sonnenschein \& Reyer 1983), nest relief has been described. This is coordinated by the mates acoustically, mainly by duetting. In $L$. aethiopicus, a bird on eggs would never call, but would leave the nest before calling to its mate. In L. funebris, incubating birds did call frequently on or near the nest. Tarboton (1971) gives an account of the situation for $L$. atrococcineus, saying that "no special behaviour was observed", but two sentences later he 
TABLE 1

BEHAVIOUR, HABITATS AND DISTRIBUTION OF MALACONOTID SHRIKES

PLUMAGE: $(+)$ MONOMORPHIC, $(-)$ DIMORPHIC; DUET SINGER: $(+)$ DUETS REPORTED, $(-)$ NO DUETS REPORTED; HABITS: $(+)$ SKULKING, $(-)$ PERCHING BEHAVIOUR; FEEDING POSITION: $(+)$ LOW FEEDER, FORAGING ON THE GROUND OR LOW IN THE VEGETATION, $(-)$ TREE-TOP FEEDER; NEST POSITION: $(+)$ NEST BELOW $4 \mathrm{M},(-)$ NEST ABOVE $4 \mathrm{M}$; CENTRE OF DISTRIBUTION, DISTANCE FROM EQUATOR (KM): (+) NORTH, $(-)$ SOUTH.

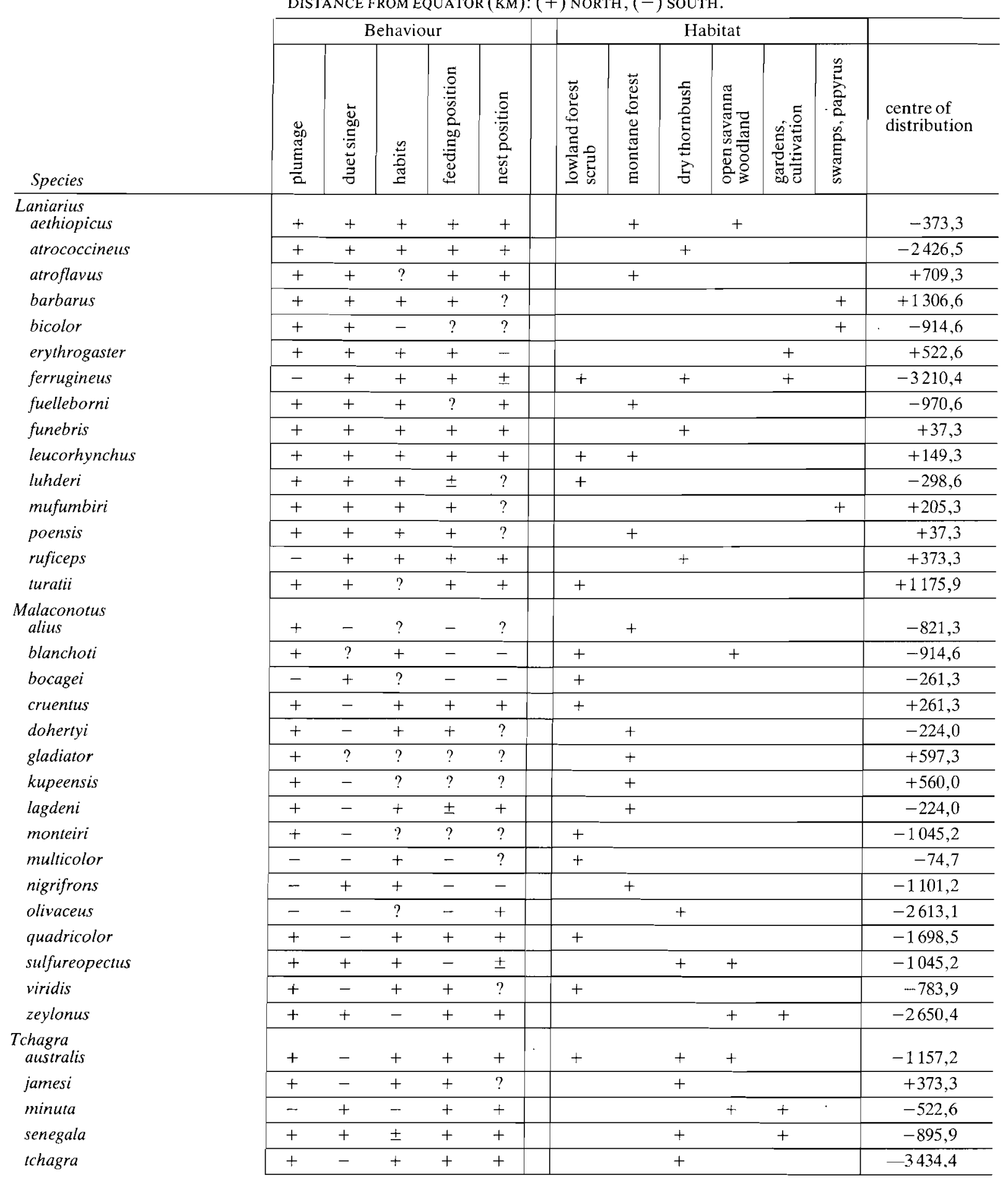


admits that "the approaching bird usually called just before arrival".

\section{General trends}

Based on the information in Table 1 we have looked for relationships between any two of the following variables:

habitat (densely wooded vs. open woodland)

plumage (monomorphic vs. dimorphic)

habits (skulking $v s$. perching)

feeding position (ground and bushes vs. treetops)

nest position (below $4 \mathrm{~m} v s$. above $4 \mathrm{~m}$ )

vocalization (duetting $v s$. non-duetting)

When all species and genera of bush shrikes were lumped, only two significant results emerged:

(a) birds that feed low tend to nest low, whereas tree-top feeders tend to nest high $\left(\chi^{2}=6,516\right.$; $\mathrm{p}=0,011)$.

(b) the proportion of monomorphic bush shrikes is higher among low-feeding species than among tree-top feeders $\left(\chi^{2}=4,637 ; p=0,031\right)$.

When Laniarius, Malaconotus and Tchagra were analyzed separately it became apparent that result (b) above may reflect differences mainly between the three genera. In Malaconotus, the genus with the highest proportion of dimorphic and conspicuously coloured species, $57,7 \%$ are tree-top feeders as opposed to $4,2 \%$ in Laniarius $\left(\chi^{2}=8,216 ; \mathrm{p}<0,005\right)$ and $0 \%$ in Tchagra $(\mathrm{p}=$ 0,054 ; Fisher exact probability test). The only other significant result was that the proportion of duetting species is lower in Malaconotus than in Laniarius and Tchagra combined (28,6 vs. 85,0\%; $\left.\chi^{2}=11,104 ; \mathrm{p}<0,001\right)$. Provided the original data are reliable, these results seem to support the widely-held opinion that duetting replaces visual cues as a means of communication where visibility is poor (e.g. when foraging on the ground in tall grass) or where plumage characters are not sufficiently diverse (e.g. in dull monomorphic species).

However, the interpretation is not all that straightforward. When all bush shrikes were analyzed together, irrespective of genus, duetting showed no significant relationship with plumage, habits, feeding height, nest position or density of the habitat. It did not show any relationship with the distribution of the birds either. We have discussed recently why, with respect to mate-guard- ing, synchronization of mates and the territorial advertisement of pairs, duetting should prevail in environments where external Zeitgeber are absent or weak as opposed to strongly seasonal environments such as the Palaearctic (Sonnenschein \& Reyer 1983). If Laniarius species occurred more frequently in such areas than Malaconotus species, this could offer another explanation for the higher proportion of duetting species in Laniarius. As a first crude test of this possibility we measured for each species the distance between the centre of its north-south distribution and the equator (using the maps in Hall \& Moreau 1970). No significant differences were found. The mean distances for Laniarius and Malaconotus were almost identical, and duetting and non-duetting species may occur in the same area (Table 1).

The above conclusions are not too surprising if one considers the crude nature of the analysis. However, before more sophisticated analyses can be applied the data base must first become broader and more reliable. The foregoing review and some tentative deductions therefrom have been presented here mainly to draw attention to the lack of data, and to stimulate further investigations into relationships between ecology and the behaviour of closely related species.

\section{REFERENCES}

Archer, G. \& Godman, E. M. 1961. The Birds of British Somaliland and the Gulf of Aden. Vol. 4. Edinburgh: Oliver \& Boyd

Bannerman, D. A. 1953. The birds of West and Equatorial Africa. London: Oliver \& Boyd.

Benson, C. W., Brooke, R. K., DowseTt, R. J. \& Irwin, M. P. S. 1973. The birds of Zambia. London: Collins.

Brown, C. W. \& BALDA, R. P. 1977. The relationship of habitat quality to group size in Hall's Babbler (Pomatostomus halli). Condor 79: 312-320.

Chapin, J. P. 1954. The birds of the Belgian Congo. Part 4. Bull. Amer. Mus. Nat. Hist. 75 B.

FoLSE, L. J. 1975. Ecology of insectivorous birds. SRI Ann. Report 1974-75: 155-170. Arusha, Tanzania.

Grimes, L. G. 1976. The occurrence of co-operative breeding behaviour in African birds. Ostrich 47: 1-15.

Hall, B. P., Moreau, R. E. \& Galbraith, I. C. J. 1966. Polymorphism and parallelism in the African bushshrikes of the genus Malaconotus (including Chlorophoneus). Ibis 108: 161-182.

Hall, B. P. \& Moreau, R. E. 1970. An atlas of speciation in African passerine birds. London: Brit. Mus. Nat. Hist.

HoOKer, T. \& HoOKer, B. I. 1969. Duetting. In Bird vo- 
calizations (Hinde, R. A., ed.). Cambridge Univ. Press: $185-205$.

IRWIN, M. P. S. 1981. The birds of Zimbabwe. Salisbury: Quest.

KaUmanNs, W. 1975. Haltung und Zucht von Boubous oder Flötenwürgern (Laniarius ferrugineus). Gef. Welt 99: 209-212.

LANGLEY, C. H. 1983. Notes on the breeding and diet of the Southern Boubou. Ostrich 54: 172-173.

LoueTTE, M. 1981. The birds of Cameroon. An annotated check-list. Brussel: Palais Acad.

Mackworth-Praed, C. W. \& Grant, C. H. B. 1955. Birds of Eastern and North Eastern Africa. Vol. 2. London: Longmans, Green \& Co.

Mackworth-Praed, C. W. \& Grant, C. H. B. 1973. Birds of West Central and Western Africa. Vol. 2, London: Longmans.

McLachlan, G. R. \& Liversidge, R. 1980. Roberts' birds of South Africa. Cape Town: Trustees of the John Voelcker Bird Book Fund.

NORTH, M. E. \& HAAGNER, H. C. 1964. Voice variation in the Boubou Shrike Laniarius ferrugineus (Gmelin). Ostrich Suppl. 6: 509.
Serle, W. \& Morel, G. J. 1980. A field guide to the birds of West Africa. London: Collins.

SonNensCheIn, E. \& ReYer, H.-U. 1983. Mate-guarding and other functions of antiphonal duets in the Slatecoloured Boubou (Laniarius funebris). Z. Tierpsychol. 63: 112-140.

TARBOTON, W. R. 1971. Breeding biology of the Crimson-breasted Shrike at Olifantsfontein, Transvaal. Ostrich 42: 271-290.

ThORPE, W. H. 1972. Duetting and antiphonal song in birds. Behaviour Suppl. 18.

Wickler, W. 1972. Aufbau und Paarspezifität des Gesangsduettes von Laniarius funebris. Z. Tierpsychol. 30: 464-476.

WICKLER, W. \& SEIBT, U. 1979. Duetting: a daily routine of Laniarius funebris, the Slate-coloured Boubou (Aves, Laniidae). Z. Tierpsychol. 51: 153-157.

WICKLER, W. \& SEIBT, U. 1982. Song splitting in the evolution of duetting. $Z$. Tierpsychol. 59: 127-140.

Williams, J. G. \& ArLoTt, N. 1980. A field guide to the birds of East Africa. London: Collins.

Wolters, H. E. 1982. Die Vogelarten der Erde. Hamburg: Parey. 